objective of his telescope, discovered a small binuclear, planetary nebula. Its position for 1880 is $R$. A. $2 \mathrm{lh}$. 2m. I1.8s, Dec. $47^{\circ} 22.2^{\prime} \mathrm{N}$.

Washington, December 23, 1880 .

W. C. WV.

\section{SWIFT'S COMFT.}

The following are two more positions of this comet. These were obtained by the aid of a ring micrometer. Nov. 20, 1880, R. A. Ih. 6m. 24s. : Dec. $+54^{\circ} 22^{\prime} 39^{\prime \prime}$ : Time is $10 h .49 .1 \mathrm{~m}$. Washirigton $\mathrm{m}$. $t$. Dec. 5. $1880, \mathrm{R}$. A. 4 h. $7 \mathrm{~m}$. 49.2s. : Dec. $+48^{\prime}$ '30' $10^{\prime \prime}$ Time is 9 h. $49 \mathrm{~m}$. Washington in.t. I have also an observation of position for Nov. 7, which has not been reduced as I have not yet managed to find the position of a fitth magnitude star, to which the comet's position was referred. The star's position will soun be obtained.

Nashville, Tenn., Dec, 2I, 1880. E. E. BAKNAKD.

\section{NEIV COMPANION TO ; FORN.ICIS.}

Sir John Herschel entered this as No. zitit, of his Fifth Catalogue of Double Stars, by reason of a distant eleventh magnitude which he detected, at an estimated distance of $45^{\prime \prime}$, in the direction of 1694 . This star was measured by me in 1879 in connection with a series of observations of a class of stars given in "Smyth's Bedford Cattilogue." Since then, in repeating the measure of the Herechel Star, I hive discovered a much nealer compontent, which fairly entille's the larges star to be elitsised ats double. The new star is very faint, and a rither ditficule ohjece with

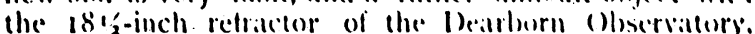
This, however, is partly due to its low altitude in this latitude, it being $25^{\prime}$ south of the liquator. 'The mean result of my measures of these companions on four nights is :-
$A$ and $B \quad P=144.4^{\circ}$
$A$ and $C \quad 157.0^{\circ}$
$D=11.53^{\prime \prime}$ $+8.85^{\circ}$
1850.93 I8So.6s

I have estimated the new companion as thirteenth magnitucle. This, it will be remembered, is in the struve scale: of magnitude's, which would mitke it rery much smiller than llerschel's twentieth mitgnitule.

The place of the principall stat for 1880 is :--

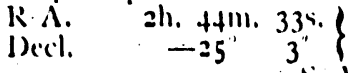

Cincalio, Illsi, llecember as, $188 \%$.

S. W. BURNHAM.

\section{Ji) the lidtitur of Sintincti:}

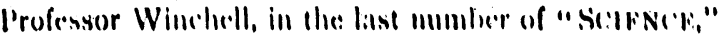

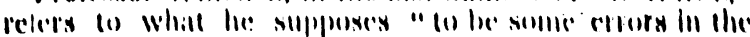

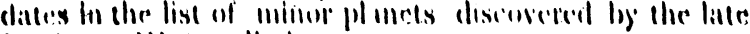
l'rutessor Wiltsom," viz.:

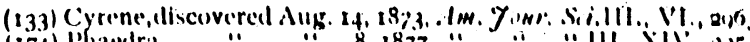

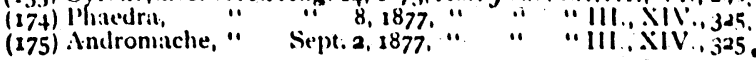

In correcting these supposed errors Prof. Winchell has fallen into more grievous ones.

(O)ving to a misprint in the elstronomische' N'achrichten I was led to record the date of the discovery of (133) as dugust 26; it should be Aupust 16, vidl. Astrims. Nincll.

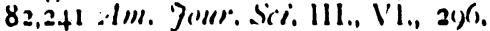

$(17+)$ Phacelra wats discovered september 2, 1577, viel. .1m. Four. Sici. III., NIV. 325. This dilte is viven September 3 in Circ. lierl. Falir. No. 76. Siptember 2 is undoubtedly the correct ditte. The object discovered August 8 turned out to be $(1+1)$ Lumen, vid. III. XIV. 429, (irc. lierl. Fuller. No. 76.

(175) Indromache was discovered ()ctoher 1,1877 , vid. Aistroll. Aisch. 91-127; ilso circ. Birl. 7ahr. No. S1.

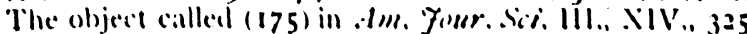

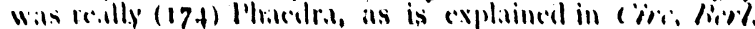
Yille. No, 81. A ARIN N. SRINSIK.

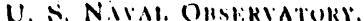

WAsllington, 1).(‥1)ec, 22, 1880.

\section{BOTANY.}

Pilosity as a Teratological. Phenomenon.-Hithetto teratologists have considered undue pilosity, or the adventi tous production of hair in plants, as a matter of minor im portance, but M. Ed. Heckel, in a recent note to the Frenct Academy, (Comptes Rendus, xci., p. 3+9), insists that there are certain phases of this sort of change in plants which have a hizher significance than that of a simple variation. He proposes to divide the phenomenon into the following three categories :

(t.) Physiols'ical Pilosity, which includes the formation of hairs, or the increase in number of these, on the parts of plants where they are normally present, or even entirely wanting. Such cases are oftenest seen when plants change their habitat from a wet to a dry soil. This sort of physio logical adaptation takes place within quite narrow timits and it varies from glabrousness to pilosity unaccompanied by any alteration of specitic characters.

(2.) Tiratolevical Pilosit!, which begins at the moment the specific habit is alteres, and acquires its maximum when the moditications are profound enoush to sug. gest the ideal of a new specie's. A large number of conditions capable of producing nutritive troubles in piants may give rise to this peculiar phenomenon, which M. Heckel proposes to introduce into teratological literature under the distinctive term of "Deforming Pilosity" (P'ilusismt difor. litant).

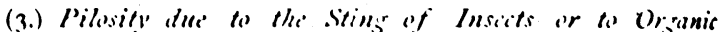
Iintirtions, which is clearly distinguished from the former in being vere locilieed (c. gr. cortivin galls, the filaments of

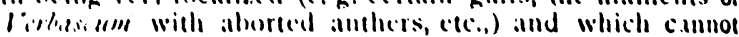
chathere the hibit of the spercies.

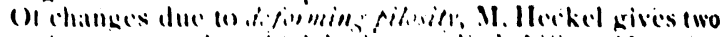

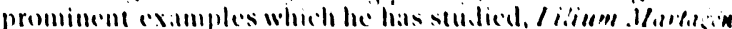

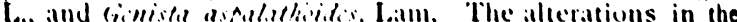
last named plant are so profound that its munstrous state has even been described by De ('andolle as a species, under the name of $G$. Leliclii: while by MIorris it has been regard. ed as a marked variety, and named by him var. confirtior.

\section{NICROSCOUY'.}

The rematiks of the " Fellow of the Rojal Mlicroscopical

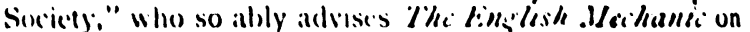
Microsiony, (1In the fitulty construction of mitny forms of "Situdent's" microscopeses, is well timed.

In regitrd to the system of gectling as much as possible for the monley, he silys: "It is just this petty ecomomy in the original outlay on a pritctical stand that cramps the studernt when he hats aleyurred some manipulatwe dex-

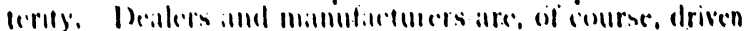

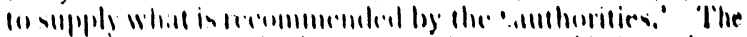

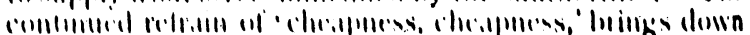

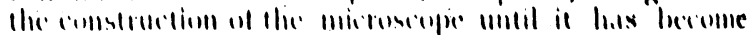

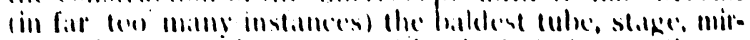
rore, objective, and eyepiece with which it is possible to view a specte of salivia on a slip of platss. 'This perpetual reduction of the finish and design of the microscope tends to exclucle all the better opticians from supplying students microsicopes, for they cannot do justice to themselies when the price is to be cut down as it has been during the last fell jears. The consequence is that an enormous number of cominon fircuch or (ierman instruments hats been imported into this country and America: students hatie been' set up " with these things, to discover later on, when they have become experienced enough to judge of such matters, that they haie no market value exicet as lumber.

The selere competition, lately, has been mainly contined to the production of lini-pricied microscopess, not the production of an efficient instrument at a moderate cosit; the consecfuence appesurs to have been that manuficturers whose appliances are about eryual to the task of

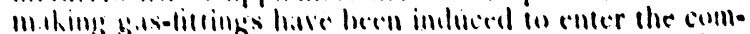

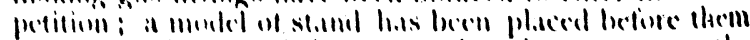

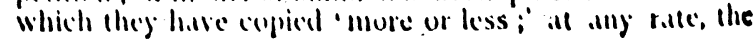

